\title{
Conflict of Government Policy in Tolitoli Regency, Central Sulawesi Province
}

\author{
Andi Pasinringi ${ }^{1}$, Darwis ${ }^{1}$, Sasterio ${ }^{1}$, Muhammad Ahsan Samad ${ }^{1}$ \\ andipasinringiuntad@gmail.com \\ ${ }^{1}$ Faculty of Social and Political Sciences, Tadulako University, Palu-Indonesia
}

\begin{abstract}
This study aims to determine how the policy conflict between the Regent and Deputy Regent of Tolitoli Regency, Central Sulawesi Province. The basis of research is carried out with a qualitative approach, while the type of research is exploratory. This research was conducted in Tolitoli Regency with the basis of the problem being the conflict of Regent Moh. Saleh Bantilan with Deputy Regent ABD Rahman Hi. Buddin. In this study, it was found that the root causes of conflict were conflicts of political interest in policies and authority to organize the Bureaucratic Structure in the levels of the Tolitoli Regency Regional Government which occurred in the two periods 2010-2015 and 2015-2020. The data collection techniques used are; first, literature study, by searching literature and documents related to the scope of research. second, in-depth interviews with research informants who have been determined purposively. The results of the study revealed that there was a political policy conflict between the Regent, Moh. Saleh Bantilan with his representatives for two periods, in which Moh Saleh Bantilan monopolized the authority in carrying out his duties and functions as Regent whose authority is regulated in Regional Government Law Number 23 of 2014. And this Law does not explicitly and clearly regulate the powers and the obligations of regional heads and deputy regional heads. Thus, the Political Policy conflict occurred, as a result of the transactional political construction agreed upon by both parties when they were candidates for regent and deputy regent, and after being elected as Regent / Deputy Regent, there was a split between the Regent and his deputy. Regional Government bureaucracy does not work professionally.
\end{abstract}

Keywords: Conflict, Policy, Authority, Local Government

Received: October 26, 2020

Received in Revised: November 8, 2020

Accepted: November 10, 2020

\section{Introduction}

Public policy is a guideline for action because it relates to a wider background. It is important to realize philosophies, ideas, visions and decisions that are translated into different programs, projects and activities (Khan \& Khandaker, 2016). Public policy demands a more complete picture that requires more than a handful of unique or extraordinary cases to get the larger context provided by a large representative sample (Shane, 2018). Agreements can be trusted to 'automatically' contribute to political progress or those related to policies in contemporary policymaking, just as success is often seen to stem from agreement on a legitimate solution to a problem (Landau, 2020). Rather than examining the program's priority policy movements themselves, we are more interested in how policy conflicts work, and precisely how, together with the articulation of neoliberalism / anti-neoliberalism and intellectual independence, discourse and participants are involved in the movement (Aikens \& Hargis, 2019).

Public policy conflicts include two or more stakeholders. Those who participate in public policy conflicts determine the characteristics of the conflict. the characteristics or categories 
of public policy conflicts vary depending on the aims of the researcher. This study categorizes conflicts into conflicts over authority and conflicts over policy (Lim \& Kwon, 2019). Indeed, implementation may not be advisable to be effective for various reasons, such as a lack of focus on the implementation process when determining system level policies; a lack of awareness that people can be at the center of the transformative process; and the need to revise the implementation process to suit the new and complex government system. Therefore, it is important to find out, explain the determinants, and find ways to make them more transparent and efficient (Viennet, $\mathrm{R}$ and Pont, 2017). To ensure that objectivity is upheld and people in the public are open to scrutiny, conflicts of interest are important and must be investigated. Effective governance and trust in government policies and policy decisions are needed to recognize and avoid or resolve conflict of interest situations (Newton, Lloyd-Williams, Bromley, \& Capewell, 2016).

Uncovering different perceptions of policy problems is not an indication of a policy conflict. Policy conflicts occur where entities, with their policy roles, claim the government through their policy positions. Conflict intensity can be assessed based on (1) the level of differences in policy views, (2) if individuals feel intimidated by other people from different policy positions, and (3) the extent to which individuals can negotiate to make compromises (Heikkila, Weible, \& Olofsson, 2017 ). Therefore, from a complex and networked point of view, there is a need to examine value conflicts, recognize the interrelationships between competing values at the same time and through the construction process, examine their impact on project networks, and fundamentally how value conflicts are resolved ( Zhu, Sun, Wang, Sun, \& Yu, 2019).

The phenomenon of conflict of political interests of regional heads becomes potential and often occurs in fact based on the Regional Government Law Number 23 of 2014 which gives greater authority to regional heads than deputy regional heads. In political legitimacy, the Regional Head and his Deputy are a system of packages that are matched against the battle. The regional head and his deputy each have political calculation considerations: First, each has the same relative popularity. Second, both figures have a consideration of the mass base of culture (ethnicity, religion and local community). Third, have a political party base and its cadres as part of the political machine. Fourth, both figures have a successful team ready to win the regional head election battle.

According to the author, the leadership of the Regent M. Salih Bantilan with his deputy was quite phenomenal. This has never happened to any other regent leadership in Indonesia. However, what is more important in this research is the impact of morality and political ethics on society and the potential for social conflicts between ethnic Tolitoli and ethnic Bugis, each of which has a mass base of supporters in regional head elections.

Political policy conflicts at the level of the political elite in government are rife and massive among the public. The political elite who occupies the top leadership of the regional government is the general election selection process which is the best choice for the people. The people's choice is a hope in creating a democratic quality that has an impact on improving the quality of people's welfare. The community becomes the subject of development, choosing their leader to protect and guide the community in the area. Of course, the leadership has ethics and morality as the face of the fortress in running the local government. The bastions of morality and government and political ethics can collapse and collapse if the government elite experiences moral decadence. Moral decadence is often seen in the drama of emotional debate, political quarrels, and acts of thuggery. A form of behavior by public leaders that is not praiseworthy and can be given social sanctions. Therefore, the 
conflict between the Regent and Deputy Regent of Tolitoli reflects how our political elite is "unhealthy" and is experiencing moral and ethical degradation.

The conflict between the Regent and Deputy Regent of Tolitoli, which occurred for two periods, shows that government management is not effective. The leader should be given social sanctions. Such leaders must be taught Pancasila as a basis for morality and in managing local government. Therefore, this research becomes urgent because it is related to the future of the region in the life of the nation and state. Leaders do not set a bad example, so it can have an impact on the community's lack of respect for their leaders. The urgency of this then deserves and deserves to be examined in the context of research: What were the causes and sources of the conflict between the Regent and Deputy Regent of Tolitoli Regency during the two periods? And why do they conflict. The regional head is related to the future of community life and the continuity of regional development in Tolitoli Regency now and in the future.

\section{Methods}

Civil servants will be trusted because they have status and responsibility in certain roles, given extraordinary responsibility and authority to carry out their duties (Alfian, Niswaty, Darwis, Arhas, \& Salam, 2019). The problems described require scientific research in order to obtain an objective picture (Mohi, Alkatiri, \& Otoluwa, 2019). The data processing method used in this research is a qualitative analytic approach (Mufti, Kurnia, Karim, \& Samad, 2020) with the form and type of research as an explorative case study. Meanwhile, data collection techniques were carried out by inventorying primary and secondary data (Darwati, Samad, \& Wekke, 2019).

Qualitative methods provide results that are usually rich and detailed, offering ideas and concepts to inform your research (Musitha, 2020). Data was collected using interview techniques conducted face-to-face to analyze problems in depth (Saragih, 2019), literature study, and observations. In this study, informants who are appropriate and appropriate to provide data information consist of members of the DPRD, community leaders, bureaucrats, NGOs and academics. Interviews were recorded and transcribed. In addition, we collected publicly available reports and documents provided by interviewees (Wong \& van der Heijden, 2019). Then, the data or information is collected so that the information needed to analyze the problem is obtained (Magdalena Silawati Samosir, 2020). I am aware of the need to continue to focus on my own role in relation to participants while learning about researchers interacting with different cultures (O'Connor, 2018).

\section{Results and Discussion}

A question about understanding the problem of policy coherence: How do the material and ideational dimensions of power work together across scales and levels of jurisdiction to shape the way policies work (Vel, McCarthy, \& Zen, 2016) of local government authority in practice? Because generational and cultural differences are also a major challenge for leadership (Chaudhuri, Park, \& Kim, 2019). In Central Sulawesi Province in recent years there has been conflict between the Regent and Deputy Regent, among them the Regent of Donggala Kasman Lassa with his deputy Vera E Laruni, Regent Morowali Atripel T and deputy Moh Ashar and Regent Tolitoli Moh. Saleh Bantilan and his deputy Abd Rahman Hi Budding. However, the choice of this research is the conflict of the regional head in Tolitoli Regency. This choice was based on the consideration that there was a conflict between the Tolitoli Regent and his deputy, namely in the 2010-2015 period, between Moh. Saleh Bantilan with Amran Hi. Yahya. Second, in the 2015-2020 period, between Moh. Saleh Bantilan with Abd.Rahman Hi Budding. What is the root of the problem? 
Moh. Saleh Bantilan, as the incumbent, participated in the contest for regional head elections in Tolitoli Regency with Abd. Rahman as his Deputy. In the election of the Regent and Deputy Regent of Tolitoli in the 2015 - 2020 period. Moh. Saleh Bantilan and Abd. Rahman won the Tolitoli regional head election. However, the leadership of Regent Moh. Saleh Bantilan and Deputy Regent Abd. Rahman, approaching approximately two years, experienced a conflict related to the policy of placing the head of the Dinas (assignment of echelon II). The difference in the importance of placing the echelon II position as Head of Service has also occurred in Regent Moh Saleh and Deputy Regent Amran H. Yahya (previous period). Even though the two of them have made peace, psychologically, the local government has relatively changed behavior, so that the conflict blocks are relatively "latent". After the conflict, the Regent and Deputy Regent of Tolitoli Regency, Moh Saleh Bantilan and Abd. Rahman, had an effect on synchronizing the mechanisms of the wheels of government. Recognition and dialogue policies are not easy to achieve, nor will they produce instant results (Zartman, 2019). The State Civil Apparatus (SCA) does not trust each other because they experience polarization in two camps, namely the Moh Saleh Bantilan camp and the Abd. Rahman. In this context it can then interfere with the performance of the bureaucracy in carrying out public administration and public policy in the regions because it is motivated by the political interests of the regional head. Governance often requires the establishment of bureaucratic structures for law and order, welfare maintenance and management of business relationships (Lee, 2020).

Conflict Regent Moh. Saleh Bantilan and Deputy Regent Abd. Rahman Hi Buddin happened on January 31, 2018 in connection with the replacement of the head of the Tolitoli Regency Transmigration Service. The process of transferring Echelon II Officials Heads of Services in the Tolitoli Regency Government began with a selection by the State Civil Apparatus Commission Team. Based on the results of the meeting, the Position and Rank Advisory Board will hold a meeting in the second week of January 2018. Then the results of the meeting include inaugurating 6 (six) echelon II officials. Then the results of the meeting will be inaugurated on January 182018 when the Regent is already in Tolitoli. However, the implementation of the inauguration was delayed because there was no Regent in Tolitoli. The agreement then changed, which should have been appointed by 6 (six) Officials structurally experiencing changes to 4 (four) people. At the inauguration session at that time, the Deputy Regent of Tolitoli Abd. Rahman H Buddin took the concept of the names that would be read by the Regional Secretary of Tolitoli Regency and tore it up. At that time there was also a commotion between Regent Moh Saleh Bantilan and Deputy Regent Abd. Rahman Hi Buddin. Deputy Regent Abd. Rahman Hi Buddin felt that he was not given policy authority in regulating and determining the composition of echelon II officials (head of service) by Tolitoli Regent Moh Saleh Bantilan, even though both were directly elected by the people.

In the policy formulation and implementation stages, most disagreements have surfaced (Cha, 2016). The conflict between the Tolitoli regent and the deputy regent of Tolitoli Moh Saleh Bantilan and Abd Rahman Hi Buddin occurred because of the absence of equality and alignment of policy authority in regulating and managing the system and structure of the local government bureaucracy of Tolitoli Regency. Moh Saleh Bantilan as the regent has monopoly on policy authority in regulating the structuring of regional government, especially in the placement and transfer of service heads and echelonization of the regional government of Tolitoli Regency. Meanwhile, Abd. Rahman Hi Buddin as Deputy Regent of Tolitoli only became a "spare tire", at times the Regent Moh. Saleh Bantilan delegated political and policy authority, if deemed necessary. The Deputy Regent certainly feels the injustice in regulating the regional governance system in Tolitoli Regency. The demand for alignment of policy authority is one of the root causes of the conflict of interest between the Regent and Deputy 
Regent of Tolitoli, Moh. Saleh Bantilan and Abd. Rahman Hi.Buddin. These are all examples of situations where a conflict of interest is evident and clearly requires regulation (Ochoa, Rolando, Graycar, 2016).

The conflict between the regent and the deputy regent of Tolitoli, one of the factors was the lack of firmness in the Regional Government Law in regulating policy authority in carrying out its duties and obligations as deputy regent and positioning as "assistant" to the regent. The position of the Deputy Regent in this regional government law can carry out government management tasks if he receives a delegation of governmental duties from the regent. Therefore, based on this law, the deputy regent in this case is the representative of the Tolitoli Regent who becomes the subordinate of the Regent, so that the deputy regent is responsible to the Tolitoli Regent. Supposedly, there is legal equality in policy authority between the regent and deputy regent in carrying out their duties and obligations in regional government. The secret to the growth of every organization is job satisfaction (Naiyananont \& Smuthranond, 2017). Demands the same rights and obligations between the regents and deputy regents of Tolitoli, Moh Saleh Bantilan and Abd. Rahman Hi Buddin as demands of political legitimacy and rights in administrative law.

Organizational performance is basically the result of the output, outcome, impact, and benefit of the policy process created by an organization (Rekho Adriadi \& Deva Hariana, 2020). The political illustration above shows that in the perspective of electoral politics and representative politics, the deputy regional head has the same political legitimacy as the regional head so that there is a need for regulations and laws that explicitly regulate the authority of regional heads and deputy regional heads with equal political and legal degrees. The process of joint construction and constructive conflict suggests that the team engages in collective feelings taking. This collaborative awareness building mechanism establishes a common ground on which the team depends to organize its activities (van der Haar, KoeslagKreunen, Euwe, \& Segers, 2017). First, with a clear and firm political and legal basis, Regional Heads and Deputy Regional Heads will be avoided from "traps" seizing the influence of political policies in the regional bureaucracy. Law enforcement is one of the main jobs where people work with many people in all types of society (Kula, 2017). Second, the influence of the Deputy Regent on the ranks of regional government is not underestimated by the Dinas and Badan (structural position). Overall, communication is key to building trust, developing effective guidelines and principles. Nevertheless, it is important to note that good communication practices will not replace bad planning or misunderstanding (Nicola et al., 2020). The legal administration position of the Deputy Regional Head in making political and regional government decisions in the placement of structural officials is quite weak, because the Deputy Regional Head only has the duty to "assist" in leading the implementation of government affairs, coordinating the activities of regional apparatus, providing advice and considerations and carrying out other tasks . The duties and powers of the Deputy Regional Head are only to "assist" the Regional Head in carrying out his duties in the regional government. The word "assist" is equivalent to the Deputy Regional Head only as "spare tire". If the Regional Head needs it, then the Deputy Regional Head is then functioned. This kind of model occurred in the regional government regime in the era of the New Order Government regime based on Law Number 5 of 1974.

The conflict between regional heads and deputy regional heads that occurred in Tolitoli regency on January 31, 2018 which was displayed in a vulgar manner on social media (Vidio) illustrated to the public that during the two periods of the leadership of Regent Moh Saleh Bantilan, he experienced conflicts of interest in policy authority with his deputy. The trigger for the conflict was the unequal distribution of policy authority in placing the composition of structural officials in the ranks of the Tolitoli District Government. Social media and social 
networks change society and therefore create new tensions in local public governance, in terms of for example, protecting citizens' rights versus enforcing law and public order (de Graaf \& Meijer, 2019).

Moh. Saleh Bantilan paired with Abd. Rahman Hi Buddin in the simultaneous direct regional head elections in 2015 each had the same political contribution. The victory of the Moh. Saleh Bantilan and Abd. Rahman Hi Buddin is a win for both of them and their supporters and success team. In direct regional head elections, it is not certain that Moh. Saleh Bantilan and the number of votes obtained by Abd. Rahman Hi Buddin. Therefore, Law Number 23 of 2014 which regulates the policy authority of Regional Heads and Deputy Regional Heads is regulated firmly and clearly, especially regarding the autonomy of their respective powers. In fact, it can be regulated in a Decree of the Minister of Home Affairs. So that the Regent and Deputy Regent of Tolitoli, Moh. Saleh Bantilan and Abd. Rahman Hi Buddin can carry out the duties and authority of his policies in a clear and accountable manner that can be held accountable to the people. Because this research shows that there are gaps in the implementation of the law, it means that more action must be taken at the lateral level to ensure policy coherence (Dutta, 2020). Therefore, implementing evidence-based policies is a viable solution to achieve this goal (Kalyal, 2019).

\section{Conclusion}

Conflict between Tolitoli Regent Moh Saleh Bantilan and Deputy Regent Abd Rahman Hi. Buddin is the second series of conflicts, because previously in the First Period of 2010 - 2015 the leadership of Moh Saleh Bantilan as Regent of Tolitoli had a conflict with his deputy Amran H. Yahya. So, the conflict between the Regional Head and Deputy Regional Head in Tolitoli Regency, Moh Saleh Bantilan as the Regent has experienced two conflicts with his deputy. Of course this incident is interesting because during the two periods of leadership Moh Saleh Bantilan with different representatives experienced conflicts. Based on this research, the conflict between the Regent and Deputy Regent of Tolitoli Regency during the two periods the root of the problem was the conflict of interest in policy authority in managing the bureaucracy of the Tolitoli District Government. The conflict of interest in policy authority between Tolitoli Regent Moh Saleh Bantilan and Deputy Regent Abd Rahman Hi Buddin occurred because of a struggle for "political influence" in structuring structural officials (echelon II and III). Political influence in the local bureaucratic system of the Tolitoli Government because it is based on a commitment to "transactional politics". Transactional political construction took place at the beginning of the regional head election procession in Tolitoli Regency in 2015. In this context, of course this incident can be resolved through political communication and social communication which is good and intense in solving various political and social problems in Tolitoli Regency. The conflict over policy authority between the Tolitoli Regent and his deputy has become a bad example as a public figure and a public official who should both become role models and protect the community. Moreover, the development of Tolitoli district so far has often been hit by flash floods that have drowned several buildings and people's houses. The two regional leaders of Tolitoli district are more concerned with the interests of the welfare of their people than the egoism of their positions and the struggle for influence in the regional government of Tolitoli Regency.

\section{References}

Aikens, K., \& Hargis, K. (2019). Policy conflicts on the move: a 'mobilities' case study of neoliberal postsecondary policy. Journal of Education Policy, 34(1), 22-43. https://doi.org/10.1080/02680939.2017.1405075 
Alfian, M., Niswaty, R., Darwis, M., Arhas, S. H., \& Salam, R. (2019). Motivasi Kerja Pegawai pada Sekretariat Dewan Perwakilan Rakyat Daerah Kabupaten Gowa Employee Motivation at the Secretariat of the Regional Representative Council of Gowa Regency. Journal of Public Administration and Government, 1, 44-54.

Cha, S. H. (2016). Decentralization in educational governance and its challenges in Korea: Focused on policy conflicts between central and local government in education. Asia Pacific Education Review, 17(3), 479-487. https://doi.org/10.1007/s12564-0169448-3

Chaudhuri, S., Park, S., \& Kim, S. (2019). The Changing Landscape of Women's Leadership in India and Korea From Cultural and Generational Perspectives. Human Resource Development Review, 18(1), 16-46. https://doi.org/10.1177/1534484318809753

Darwati, D., samad, muhammad ahsan, \& Wekke, I. S. (2019). Collaborative Governance Dalam Pengelolaan Integrated Community Shelter Pasca Bencana di Kota Palu. https://doi.org/10.31227/osf.io/7kjte

de Graaf, G., \& Meijer, A. (2019). Social Media and Value Conflicts: An Explorative Study of the Dutch Police. Public Administration Review, 79(1), 82-92. https://doi.org/10.1111/puar.12914

Dutta, K. (2020). UNGP: Importance of Policy Coherence in Addressing Resource Conflicts. Journal of Human Rights and Social Work. https://doi.org/10.1007/s41134-02000134-0

Heikkila, T., Weible, C. M., \& Olofsson, K. (2017). Policy conflicts over U.S. shale development. Environment, 59(3), 4-13. https://doi.org/10.1080/00139157.2017.1301165

Kalyal, H. (2019). "Well, there's a more scientific way to do it!": factors influencing receptivity to evidence-based practices in police organizations. Police Practice and Research, 00(00), 1-15. https://doi.org/10.1080/15614263.2019.1608548

Khan, A. R., \& Khandaker, S. (2016). A critical insight into policy implementation and implementation performance. Public Policy and Administration, 15(4), 538-548. https://doi.org/10.13165/VPA-16-15-4-02

Kula, S. (2017). Occupational stress, supervisor support, job satisfaction, and work-related burnout: perceptions of Turkish National Police (TNP) members. Police Practice and Research, 18(2), 146-159. https://doi.org/10.1080/15614263.2016.1250630

Landau, F. (2020). Agonistic failures: Following policy conflicts in Berlin's urban cultural politics. Urban Studies. https://doi.org/10.1177/0042098020949080

Lee, T. (2020). Political orders and peace-building: ending the Aceh conflict. Conflict, Security and Development, 20(1), 115-139. https://doi.org/10.1080/14678802.2019.1705071

Lim, D. J., \& Kwon, K. D. (2019). Policy conflicts and factors affecting conflict resolution in South Korea: Trends from the Korean public policy conflict database (1948-2014). International Journal of Conflict Management, 31(1), 58-75. https://doi.org/10.1108/IJCMA-03-2019-0057

Magdalena Silawati Samosir. (2020). Analisis Pengaruh Kontribusi dan Efektivitas Pajak Hotel, Restoran dan Hiburan Terhadap Pendapatan Asli Daerah Pada Badan 
Pendapatan Daerah Kabupaten Sikka. Journal of Public Administration and Government, 2(1), 35-43. https://doi.org/10.22487/jpag.v2i1.38

Mohi, W. K., Alkatiri, R., \& Otoluwa, D. (2019). Journal of Public Administration and Government Kemampuan Aparat Dalam Pengelolaan Dana Desa ( ADD ) di Desa Monano Kabupaten Gorontalo Utara The Capability of the Officials in Managing Village Funds ( ADD ) in Monano Village , North Gorontalo District. Journal of Public Administration and Government, 1(2), 35-43.

Mufti, M. I., Kurnia, I., Karim, I., \& Samad, M. A. (2020). Evaluation on Community Empowerment Policy after Conflict Resolution ( A Study of Sub District Development Program in Poso District ). International Journal of Multicultural and Multireligious $\quad$ Understanding, 7(8), 16-25. https://doi.org/10.18415/ijmmu.v7i8.1792

Musitha, M. E. (2020). Perceptions of South Africans on traditional leadership: a case of Limpopo Province. African Identities, O0(00), 1-16. https://doi.org/10.1080/14725843.2020.1777840

Naiyananont, P., \& Smuthranond, T. (2017). Relationships between ethical climate, political behavior, ethical leadership, and job satisfaction of operational officers in a wholesale company, Bangkok Metropolitan region. Kasetsart Journal of Social Sciences, 38(3), 345-351. https://doi.org/10.1016/j.kjss.2016.07.005

Newton, A., Lloyd-Williams, F., Bromley, H., \& Capewell, S. (2016). Food for thought? Potential conflicts of interest in academic experts advising government and charities on dietary policies. BMC Public Health, 16(1), 1-8. https://doi.org/10.1186/s12889016-3393-2

Nicola, M., Sohrabi, C., Mathew, G., Kerwan, A., Al-Jabir, A., Griffin, M., ... Agha, R. (2020). Health policy and leadership models during the COVID-19 pandemic: A review. International Journal of Surgery, 81(May), 122-129. https://doi.org/10.1016/j.ijsu.2020.07.026

O'Connor, S. (2018). Problematising strategic internationalisation: tensions and conflicts between international student recruitment and integration policy in Ireland. Globalisation, Societies and Education, 16(3), 339-352. https://doi.org/10.1080/14767724.2017.1413979

Ochoa, Rolando, Graycar, A. (2016). Tackling Conflict of Interest: Policy Instruments in $\begin{array}{llll}\text { Different } & \text { Settings. } & \text { 입법학연구, } & \text { 83-100. }\end{array}$ https://doi.org/10.1080/10999922.2015.109339

Rekho Adriadi, \& Deva Hariana. (2020). Analisis Kinerja KPUD Dalam Peningkatan Partisipasi Pemilih Pemula Pada Pemilihan Umum 2019, Studi Di Kabupaten Seluma, Provinsi Bengkulu. Journal of Public Administration and Government, 2(1), 19-26. https://doi.org/10.22487/jpag.v2i1.36

Saragih, B. M. (2019). the Policing Model in Managing the Youth Organization Conflict in Medan, Indonesia: Case Study of Ikatan Pemuda Karya (Ipk) and Pemuda Pancasila (Pp) Conflict. International Review of Humanities Studies, 4(2), 597-609. https://doi.org/10.7454/irhs.v4i2.165

Shane, J. M. (2018). Improving Police Use of Force: A Policy Essay on National Data Collection. Criminal Justice Policy Review, 29(2), 128-148. https://doi.org/10.1177/0887403416662504 
Van der Haar, S., Koeslag-Kreunen, M., Euwe, E., \& Segers, M. (2017). Team leader structuring for team effectiveness and team learning in command-and-control teams. In Small Group Research (Vol. 48). https://doi.org/10.1177/1046496417689897

Vel, J. A. C., McCarthy, J. F., \& Zen, Z. (2016). The Conflicted Nature of Food Security Policy: Balancing Rice, Sugar and Palm Oil in Indonesia. Anthropological Forum, 26(3), 233-247. https://doi.org/10.1080/00664677.2016.1190919

Viennet, R and Pont, B. (2017). Education Policy Implementation. OECD Education Working Papers Series, (162), 375. https://doi.org/10.1787/fc467a64-en

Wong, R., \& van der Heijden, J. (2019). Avoidance of conflicts and trade-offs: A challenge for the policy integration of the United Nations Sustainable Development Goals. Sustainable Development, 27(5), 838-845. https://doi.org/10.1002/sd.1944

Zartman, I. W. (2019). Dynamics and Constraints in Negotiating Internal Conflicts. 161-172. https://doi.org/10.1007/978-3-030-06079-4_9

Zhu, F., Sun, M., Wang, L., Sun, X., \& Yu, M. (2019). Value conflicts between local government and private sector in stock public-private partnership projects: A case of China. Engineering, Construction and Architectural Management, 26(6), 907-926. https://doi.org/10.1108/ECAM-08-2018-0330 